\title{
Detection of Pyricularia grisea Causing Gray Leaf Spot of Perennial Ryegrass Turf by a Rapid Immuno-Recognition Assay
}

\author{
W. Uddin and G. Viji, Department of Plant Pathology, The Pennsylvania State University, University Park 16802; \\ G. L. Schumann, Department of Microbiology, University of Massachusetts, Amherst 01003; and S. H. Boyd, Hy- \\ dros Environmental Diagnostics, Falmouth, MA 02540
}

\begin{abstract}
Uddin, W., Viji, G., Schumann, G. L., and Boyd, S. H. 2003. Detection of Pyricularia grisea causing gray leaf spot of perennial ryegrass turf by a rapid immuno-recognition assay. Plant Dis. 87:772-778.

An immuno-recognition assay using a monoclonal antibody was developed to detect Pyricularia grisea, the causal agent of gray leaf spot of perennial ryegrass (Lolium perenne). In vitro assays with isolates of $P$. grisea from perennial ryegrass, tall fescue (Festuca arundinacea), St. Augustinegrass (Stenotaphrum secundatum), crabgrass (Digitaria sanguinalis), finger millet (Eleusine coracana), wheat (Triticum aestivum), triticale $(\times$ Triticosecale rimpaui), and rice (Oryza sativa) showed positive reactions; however, the strength of the reactions differed among isolates. Reactions were more intense with isolates from perennial ryegrass, wheat, and triticale. All $P$. grisea isolates from perennial ryegrass collected from various regions of the United States showed positive reactions. $P$. grisea was detected at antigen dilution rates of $0.5 \times, 0.25 \times$, $0.13 \times, 0.06 \times$, and $0.03 \times$. Dot-blot assays with Bipolaris sorokiniana, Colletotrichum graminicola, Curvularia lunata, Microdochium nivale, Pythium aphanidermatum, Rhizoctonia solani, or Sclerotinia homoeocarpa isolated from turfgrasses were negative. In vivo assays of symptomatic leaves of perennial ryegrass plants inoculated with $P$. grisea also showed positive reactions, and those inoculated with $B$. sorokiniana, $P$. aphanidermatum, $R$. solani, or $S$. homoeocarpa were negative. Intensity of reaction between the monoclonal antibody and $P$. grisea was proportional to disease severity in perennial ryegrass inoculated with $P$. grisea; however, there was no reaction in dot blots of leaf tissue collected during the latent period. P. grisea was detected in perennial ryegrass samples from golf course fairways affected by gray leaf spot in Connecticut, Massachusetts, Maine, New Jersey, Pennsylvania, and Rhode Island using this procedure. The monoclonal antibody recognition system is highly sensitive to $P$. grisea and can be used effectively for the rapid diagnosis of gray leaf spot of perennial ryegrass turf.
\end{abstract}

Additional keywords: blast, disease diagnosis, immuno-detection, Magnaporthe grisea, serology

Gray leaf spot (blast) of perennial ryegrass turf, caused by Pyricularia grisea (Cooke) Sacc. (teleomorph: Magnaporthe grisea (T.T. Hebert) Yaegashi \& Udagawa), is a serious problem for the golf course industry in various regions of the United States. The pathogen was first reported on perennial ryegrass fairways in Pennsylvania in 1991 (21). In 1998, a severe outbreak of gray leaf spot occurred in Pennsylvania (41) and adjacent states in the Northeast. Subsequently, it was reported from New England (35) in 1999, the Midwest in 1999 (46) and 2000 (15), and California in 2001 (42).

Gray leaf spot of perennial ryegrass is diagnosed primarily by microscopic observation of morphological characteristics of the conidia; however, turfgrass samples

Corresponding author: W. Uddin

E-mail:wxu2@psu.edu

Accepted for publication 10 March 2003.

Publication no. D-2003-0509-01R

() 2003 The American Phytopathological Society submitted to plant diagnostic clinics often lack conidia on leaf tissue. Accurate diagnosis of gray leaf spot, based solely on foliar symptoms in the turf stand or on individual plants, is difficult because symptoms of this disease resemble those of other foliar diseases such as Bipolaris leaf spot, Pythium blight, and Rhizoctonia blight (38). Depending on the condition of samples arriving at a plant disease clinic and the severity of the disease, 2 to 4 days may be required for production of conidia of $P$. grisea on symptomatic perennial ryegrass leaves and positive identification of the fungus. During this period, the disease can progress rapidly in the field under favorable conditions and may result in significant loss of turf.

Immunological methods have been used successfully for the rapid diagnosis of a number of plant diseases $(8,12,29,30)$, including diseases initiated by viruses $(3,13,16,17,23,26,37)$ and bacteria $(1,6,7$, $22,25,36,44)$. Application of immunology to detect plant-pathogenic fungi and diagnose fungal diseases has been more limited because microscopic identification of fungi is conventionally practiced. Immunological techniques have been applied successfully, however, in studies of fungal taxonomy $(2,4,18,27)$, phylogeny $(20,48)$, cell biology $(5,14,49)$, detection in natural substrates $(24,40)$, and host plant tissue $(10,11,19,31-34,39,47)$. Use of such techniques to detect pathogens in a turfgrass pathosystem has been demonstrated for Pythium blight (28), Rhizoctonia blight (29), and dollar spot (29).

To date, a rapid assay for diagnosis of gray leaf spot has not been developed, and there is a critical need in the turfgrass industry for a method that can be employed in both laboratory and field. Therefore, this study was undertaken to develop a procedure for detection of the gray leaf spot pathogen in vitro and in symptomatic perennial ryegrass turf employing immunorecognition assay.

\section{MATERIALS AND METHODS}

Maintenance of perennial ryegrass plants and isolates of turfgrass pathogens. Perennial ryegrass cv. Legacy II plants were grown in 4-cm-diameter $\times 20$ cm-deep plastic Cone-tainers (Stuewe \& Sons, Inc., 2290 S.E. Kiger Island Drive, Corvallis, OR) that were filled to $1 \mathrm{~cm}$ below the rim with granular calcine clay medium (Turface MVP, Allied Industrial Material Corp., Buffalo Grove, IL) in a greenhouse. Fifteen plants in each Conetainer were fertilized weekly with a watersoluble 20-20-20 (N-P-K) granular fertilizer (1.3 g product per liter of water) to field capacity of the growing medium.

Isolates of Bipolaris sorokiniana, Colletotrichum graminicola, Curvularia lunata, Microdochium nivale, and $P$. grisea were stored at $-20^{\circ} \mathrm{C}$ on sterilized filter paper disks (43). Two weeks prior to the laboratory assays, filter paper disks containing individual isolates of the fungi were placed on potato dextrose agar (PDA) plates and incubated at $28^{\circ} \mathrm{C}$ under $12-\mathrm{h}$ (day/night) cycles of fluorescent light $\left(76 \mu \mathrm{E} \mathrm{m}^{-2} \mathrm{~s}^{-1}\right)$. Isolates of Rhizoctonia solani and Sclerotinia homoeocarpa were stored on autoclaved rye grains at $4^{\circ} \mathrm{C}$. Four days prior to inoculation, the rye grains were placed on PDA and incubated at $28^{\circ} \mathrm{C}$ under 12 -h (day/night) cycles of fluorescent light (76

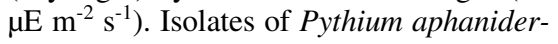
matum, stored at $20^{\circ} \mathrm{C}$ on rose bengal agar, were transferred to corn meal agar and incubated at $22^{\circ} \mathrm{C}$ under 12 -h (day/night) cycles 2 days prior to inoculation. A total 
of 34 isolates of various turfgrass and nonturfgrass pathogens were used in this study (Table 1).

In vitro assays. There were four experiments in this study. In experiment 1 , two isolates each of $P$. grisea, B. sorokiniana, Colletotrichum graminicola, Curvularia lunata, M. nivale, Pythium aphanidermatum, $R$. solani, and $S$. homoeocarpa were tested for immunorecognition by the monoclonal antibody. A 5-mm-diameter agar plug was cut from the midpoint between the center and edge of an actively growing colony of each isolate, and the adhering agar was removed by slicing it just below the mycelial mat. The mycelial mat was ground in $2 \mathrm{ml}$ of extraction buffer (TTBS, Tris $7.4 \mathrm{pH}$, Tween 20 at $0.05 \%$ in buffered saline) using a grinding pestle. The suspension was transferred to a microcentrifuge tube and centrifuged at $5,000 \times g$ for $2 \mathrm{~min}$ to remove large debris. A 1- $\mu$ l volume of supernatant was transferred to each of the $6 \times 6 \mathrm{~mm}$ printed blocks of a modified trilayered nitrocellulose-based membrane (Hydros Environmental Diagnostics, Falmouth, MA). Two replicate sample membranes were prelabeled for each treatment, including the negative control (PDA or TTBS extraction buffer) and positive control (plugs of PDA containing $P$. grisea mycelium, homogenized in phosphate buffered saline and preserved in $0.01 \%$ azide [Hydros Environmental Diagnostics]). Samples on the membrane were allowed to dry for $10 \mathrm{~min}$ or until the water-soaked spots developed the same background color as the membrane. The reaction on the membrane was blocked with $3 \mathrm{ml}$ of bovine serum albumin (BSA) TTBS buffer for $20 \mathrm{~min}$ at $22^{\circ} \mathrm{C}$, and the solution was decanted. A 2.5-ml volume of Protein A-purified primary antiserum $(0.25 \mu \mathrm{g} / \mathrm{ml}$; mouse IgG1 anti-P. grisea; Ref. PD-GLS-025, Hydros Environmental Diagnostics) was applied to the blocked membrane and swirled in a shaker at $50 \mathrm{rpm}$ for $20 \mathrm{~min}$. The primary antiserum was then discarded, and the membrane was washed with $5 \mathrm{ml}$ of wash solution $(50 \mathrm{mM}$ Tris Tween 20 buffered saline) three times and the solution decanted. After the membrane was exposed to $2.5 \mathrm{ml}$ of Protein A Alkaline Phosphatase conjugate (Sigma Chemical Co., St. Louis, MO) and gently swirled in a shaker at $50 \mathrm{rpm}$ for $20 \mathrm{~min}$, it was washed three times with distilled water and blotted dry. The dot blots were then exposed to alkaline phosphatase substrate (BCIP/NBT; BCIP $0.692 \mathrm{mMol} / \mathrm{L}-\mathrm{NBT} 0.734 \mathrm{mMol} / \mathrm{L}$, Moss Inc., Pasadena, MD), and development of the background color was visually monitored. After $3 \mathrm{~min}$, as the background color of the membrane gradually began to turn purple, the reaction was stopped by washing the membrane with distilled water.

In experiment 2 , the effect of antigen dilution on sensitivity of detection was tested by increasing the volume of extraction buffer solution to $2 \times, 4 \times, 8 \times, 16 \times$, and $32 \times$ using two isolates of $P$. grisea (19W-01 and $02 \mathrm{~V}-01$ ). This experiment was performed as in experiment 1, except that the five dilution rates of extraction buffer solution were used in addition to the primary concentration. In experiment 3 , isolates of $P$. grisea from perennial ryegrass fairways from various regions of the United States were tested using the immuno-recognition procedure. These included one isolate each from Kansas (KS3-1), Maryland (MD1-1), New Jersey (NJ1-2), Virginia (VA13-6), and West Virginia (WV17-5). In order to determine the relative sensitivity of these isolates to the monoclonal antibody, the Pennsylvania isolate (PA02V-01), which was tested previously in experiment 1 , was used as a standard. Since the dot blot reaction of the standard isolate was evaluated previously along with the positive and negative controls, only the isolates from different regions were compared with the standard isolate in this experiment. In experiment 4, two isolates of $P$. grisea per host species (perennial ryegrass, tall fescue, St. Augustinegrass, finger millet, rice, crabgrass, wheat, and triticale) were tested for signal detection. Additionally, leaf samples from symptomatic plants inoculated with $P$. grisea isolate $02 \mathrm{~V}-01$ (centrifuged suspension) and cultures of $B$. sorokiniana, Pythium aphanidermatum, $R$. solani, and $S$. homoeocarpa were included in this experiment. Additionally, leaf samples from symptomatic plants (inoculated with $P$. grisea isolate PA02V-01) and cultures of B. sorokiniana, Pythium aphanidermatum, $R$. solani, and $S$. homoeocarpa were included in this experiment. The procedure for experiments 3 and 4 was the same as that of experiment 1 . All experiments were repeated once.

Inoculation of perennial ryegrass plants. Isolates of $P$. grisea were grown on oatmeal agar for the production of conidia. Similarly, isolates of $B$. sorokiniana, $P y$ thium aphanidermatum, $R$. solani, and $S$. homoeocarpa were also grown on PDA to supply the conidia or mycelial plugs for inoculation. After conidia of 10- to 12-dayold cultures of $P$. grisea and $B$. sorokiniana were harvested by washing plates with distilled water and a soft brush, the suspension was filtered through four layers of cheesecloth. Seven-week-old perennial ryegrass plants were inoculated with conidia $\left(8 \times 10^{4}\right.$ conidia/ml of aqueous sus-

Table 1. Isolates of fungal pathogens from various turfgrass and nonturfgrass hosts used in immunorecognition assays

\begin{tabular}{|c|c|c|c|c|}
\hline Fungal pathogen & Isolate & Host of origin ${ }^{a}$ & Location & $\begin{array}{l}\text { Year of } \\
\text { collection }\end{array}$ \\
\hline Bipolaris sorokiniana & $98-5068-\mathrm{A} 2$ & Lolium perenne & Pennsylvania & 2000 \\
\hline B. sorokiniana & $98-5068-\mathrm{A} 3$ & L. perenne & Pennsylvania & 2000 \\
\hline $\begin{array}{l}\text { Colletotrichum } \\
\text { graminicola }\end{array}$ & $00-5001-3$ & Роа аппиа & Pennsylvania & 2000 \\
\hline C. graminicola & Val-PO-4 & P. annua & Pennsylvania & 2000 \\
\hline Curvularia lunata & $\mathrm{C}-10$ & L. perenne & Unknown & Unknown \\
\hline C. lunata & $00-5065 \mathrm{~A}$ & Cynodon dactylon & Louisiana & 2000 \\
\hline Microdochium nivale & $99-13$ & L. perenne & Pennsylvania & 1999 \\
\hline$M$. nivale & $98-5020-1$ & L. perenne & Pennsylvania & 1998 \\
\hline Pyricularia grisea & $02 \mathrm{~V}-01$ & L. perenne & Pennsylvania & 1998 \\
\hline$P$. grisea & 19W-04 & L. perenne & Pennsylvania & 1998 \\
\hline$P$. grisea & 19W-06 & L. perenne & Pennsylvania & 1998 \\
\hline$P$. grisea & WV17-5 & L. perenne & West Virginia & 1998 \\
\hline P. grisea & NJ15-3 & L. perenne & New Jersey & 1998 \\
\hline P. grisea & NJ1-2 & L. perenne & New Jersey & 1995 \\
\hline P. grisea & VA13-6 & L. perenne & Virginia & 1998 \\
\hline P. grisea & MD1-1 & L. perenne & Maryland & 1995 \\
\hline$P$. grisea & KS3-1 & L. perenne & Kansas & 1995 \\
\hline$P$. grisea & TF662 & Festuca arundinacea & Georgia & 1999 \\
\hline$P$. grisea & TF731 & F. arundinacea & Georgia & 1999 \\
\hline$P$. grisea & FAG9.2.1 & Stenotaphrum secundatum & Florida & 1998 \\
\hline P. grisea & AG126 & S. secundatum & Georgia & 1999 \\
\hline P. grisea & PB3.1.2 & Eleusine coracana & India & 1994 \\
\hline P. grisea & PA3.1.4 & E. coracana & India & 1994 \\
\hline P. grisea & $0-137$ & Oryza sativa & China & 1985 \\
\hline$P$. grisea & G-158 & $\times$ Triticosecale rimpaui & Brazil & 1988 \\
\hline$P$. grisea & $\mathrm{T}-29$ & Triticum aestivum & Brazil & 1989 \\
\hline P. grisea & CB31V-01 & Digitaria sanguinalis & Pennsylvania & 1999 \\
\hline P. grisea & CB31V-03 & D. sanguinalis & Pennsylvania & 1999 \\
\hline Pythium aphanidermatum & $\mathrm{P}-1$ & L. perenne & Pennsylvania & 1974 \\
\hline P. aphanidermatum & $\mathrm{P}-38$ & L. perenne & Pennsylvania & 1988 \\
\hline Rhizoctonia solani & $\mathrm{Rh}-7$ & L. perenne & Pennsylvania & 1993 \\
\hline R. solani & Rh-57B & L. perenne & Pennsylvania & 1996 \\
\hline Sclerotinia homoeocarpa & S-9 & L. perenne & Virginia & Unknown \\
\hline S. homoeocarpa & S- 84 & L. perenne & Pennsylvania & 1974 \\
\hline
\end{tabular}

${ }^{a}$ Lolium perenne (perennial ryegrass); Poa annua (annual bluegrass); Cynodon dactylon (Bermudagrass); Festuca arundinacea (tall fescue); Stenotaphrum secundatum (St. Augustinegrass); Eleusine coracana (finger millet); Oryza sativa (rice); $\times$ Triticosecale rimpaui (triticale); Triticum aestivum (wheat); Digitaria sanguinalis (crabgrass). 
pension with $0.1 \%$ Tween 20 ) of $P$. grisea or $B$. sorokiniana by spraying the leaves with an atomizer (Model 15, DeVilbiss, Sunrise Medical, Inc., Somerset, PA) until runoff. Inocula for Pythium aphanidermatum, $R$. solani, and $S$. homoeocarpa were prepared by cutting $4 \mathrm{~mm}^{2}$ agar blocks from the edge of the 3-day-old fungal colonies. The agar blocks were then placed on the perennial ryegrass leaves in Conetainers assigned to each pathogen. After inoculation, each Cone-tainer was covered
A

a

b

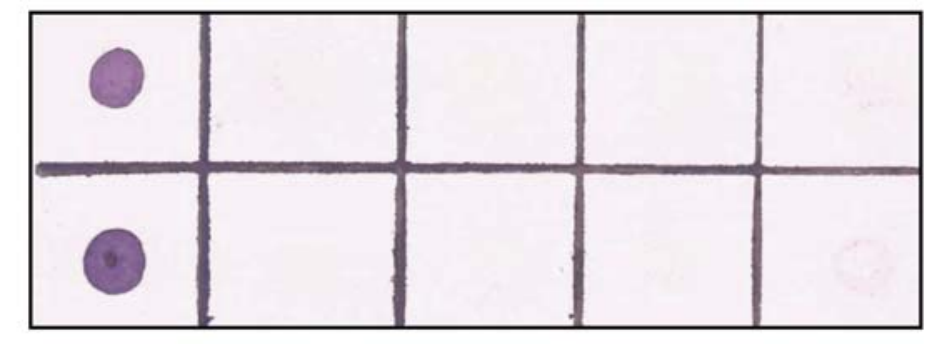

1

2

B

a

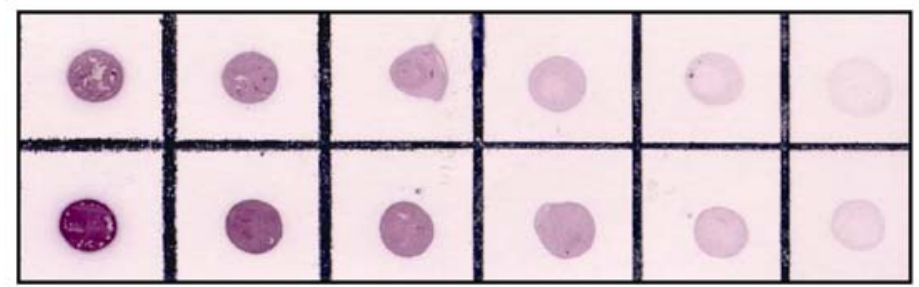

12

3

4

5

6

C

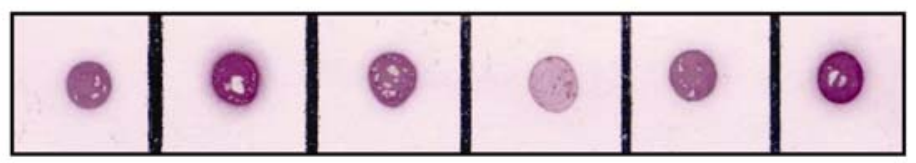

1

2

3

4

5

D

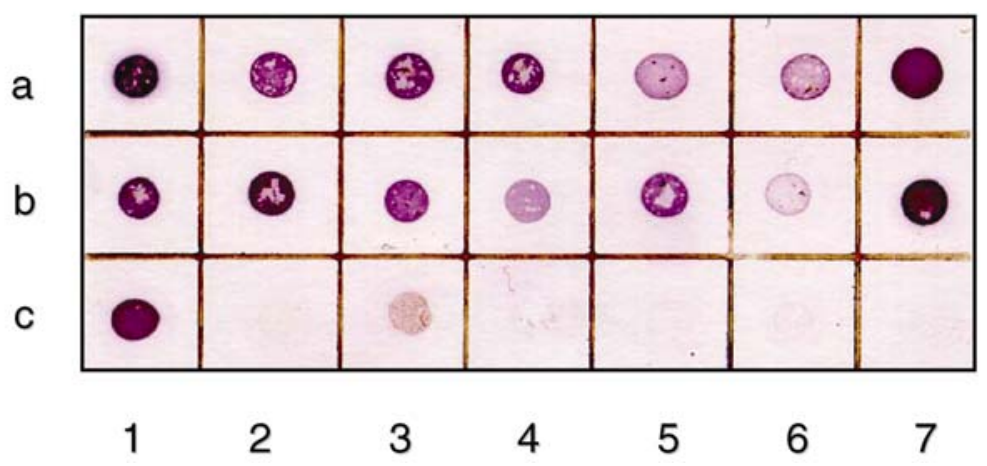

Fig. 1. A, Dot blots of reactions by fungal turfgrass pathogens in immuno-recognition assay. a $1=$ Pyricularia grisea $;$ a2 = Sclerotinia homoeocarpa $;$ a3 = Bipolaris sorokiniana $;$ a4 = Colletotrichum graminicola; a5 = Pythium aphanidermatum; $\mathrm{b} 1=$ positive control; $\mathrm{b} 2=$ extraction buffer; $\mathrm{b} 3=$ Curvularia lunata; b4 = Rhizoctonia solani; b5 = Microdochium nivale. $\mathbf{B}$, Effects of antigen dilution on detection of $P$. grisea in vitro. Rows: . grisea (perennial ryegrass) isolates: a $=$ PA02V-01; b $=$ PA19W-04; columns: antigen dilution series: $1=$ primary conc.; $2=0.5 \times$; a $3=0.25 \times ;$ a $4=0.13 \times$; a5 $=0.06 \times$; a6 $=0.03 \times$ dilution. $\mathbf{C}$, Dot blots of reactions by $P$. grisea isolates from various regions of U.S. in immuno-recognition assay: 1 = VA13-6 (VA); 2 = WV17-5(WV); 3 = PA02V-01 (PA); $4=$ NJ1-2 (NJ); 5 = MD1-1 (MD); $6=\mathrm{KS} 3-1(\mathrm{KS})$. D, Dot blots of reactions by $P$. grisea isolates from various gramineous hosts: a1 (isolate $02 \mathrm{~V}-01$ ), b1 (isolate $19 \mathrm{~W}-04$ ) = perennial ryegrass; 2 2, b2 = tall fescue; a3, b3 = St. Augustinegrass; a4, b4 = finger millet; a5, b5 = rice; a6, b6 = crabgrass; a7 = wheat; $\mathrm{b} 7=$ triticale; $\mathrm{c} 1=$ positive control; $\mathrm{c} 2=$ healthy leaves; $\mathrm{c} 3=$ gray leaf spot blighted leaves (noncentrifuged); $\mathrm{c} 4=R$. solani; $\mathrm{c} 5=$ B. sorokiniana $; \mathrm{c} 6=$ Pythium aphanidermatum; $\mathrm{c} 7=S$. homoeocarpa. with a polyethylene bag and sealed. The plants were placed under continuous fluorescent light $\left(155 \mu \mathrm{E} \mathrm{m}^{-2} \mathrm{~s}^{-1}\right)$ at $28^{\circ} \mathrm{C}$ and $95 \%$ relative humidity in a growth chamber (Conviron PGR15; Controlled Environment Limited, Winnipeg, Manitoba, Canada). There were four replications of the treatments (fungi). Plants sprayed with sterile distilled water served as controls. In order to obtain symptomatic plants simultaneously, grasses were inoculated with isolates of B. sorokiniana, Pythium aphanidermatum, Pyricularia grisea, $R$. solani, and $S$. homoeocarpa 8, 4, 5, 4, and 4 days prior to the immuno-recognition assay, respectively. The in vivo immunorecognition assay was conducted 2 days after development of symptoms in 8- to 10$\mathrm{cm}$-tall plants, when partial blighting of the leaves occurred.

Removal of chlorophyll from leaf tissue. Chlorophyll was removed from dot blots in order to eliminate the green color that interfered with the purple color of positive assays. In this experiment, 201 $\mathrm{cm}$-long segments of asymptomatic leaves from noninoculated 7-week-old plants were placed in a $5 \times 8 \mathrm{~cm}$ polyethylene bag, in which $2 \mathrm{ml}$ of extraction buffer was added, and the plant tissue was homogenized using a plastic pestle. A $1-\mu$ l volume of leaf tissue or $P$. grisea mycelium from each tube was placed on a $6 \times 18 \mathrm{~mm}$ modified trilayered nitrocellulose-based membrane as previously described. Each membrane was immersed in 5.25, 2.62, $1.0,0.5$, or $0.05 \% \mathrm{NaOCl}$ for $4 \mathrm{~min}$, rinsed with distilled water, and blotted dry. The experiment was repeated once.

In vivo assays. There were two experiments in this study. In the first experiment, 20 symptomatic leaves each from plants inoculated with B. sorokiniana, Pythium aphanidermatum, Pyricularia grisea, $R$. solani, or $S$. homoeocarpa were collected, and the tip and base of each leaf were removed with a scalpel, retaining 1-cm-long segments of leaf tissue. The leaves were homogenized in $2 \mathrm{ml}$ of extraction buffer in a $5 \times 8 \mathrm{~cm}$ polyethylene bag using a plastic pestle. The suspension was transferred to a microcentrifuge tube and centrifuged at $5,000 \times g$ for $2 \mathrm{~min}$ to remove large debris, and the immuno-recognition test was conducted following the procedure described in the in vitro assay. After exposure to the alkaline phosphatase substrate, two replicate membranes were immersed in a $0.5 \% \mathrm{NaOCl}$ solution for $3 \mathrm{~min}$ for removal of chlorophyll. The membranes were then washed with distilled water and blotted dry.

In the second experiment, $201-\mathrm{cm}$-long segments of asymptomatic leaves from plants inoculated with $P$. grisea 2 and 3 days after inoculation, symptomatic leaves (low, moderate, and high disease severity) sampled from inoculated plants 5 days after inoculation, and leaves from noninoculated plants were collected. The leaves were ho- 
mogenized in $2 \mathrm{ml}$ of extraction buffer in a 5 $\times 8 \mathrm{~cm}$ polyethylene bag using a plastic pestle, and the immuno-recognition test was conducted following the procedure described in the first experiment. Both experiments were repeated once.

Analysis of turfgrass samples from golf courses. In 2000, a survey was conducted to monitor gray leaf spot in perennial ryegrass fairways at 20 golf courses in Connecticut, Massachusetts, New Jersey, New York, Pennsylvania, and Rhode Island. Three 10 -cm-diameter $\times 5$-cm-deep samples were collected from each course (seven from Connecticut, one each from Massachusetts, New York, and Rhode Island, eight from Pennsylvania, and two from New Jersey) biweekly in June and July and weekly in August and September. Samples from three additional golf courses in Pennsylvania were taken once every 2 weeks during the sampling period. Upon arrival at the laboratory, each sample was divided into two equal sections. One half was placed in a $30 \times 15 \times 15 \mathrm{~cm}$ plastic chamber lined with moist paper towels in order to confirm the identity of the causal agent. Two to 4 days later, 20 symptomatic, senescing, or dead leaves per chamber were collected, and $P$. grisea was identified by morphological characteristics of conidia (9). Necrotic or partially to completely blighted leaves were selected from the second half of each sample and processed for detection of $P$. grisea using the immuno-recognition procedure described in the in vivo assay. Senescing or dead leaves were used for analysis of samples that did not exhibit characteristic gray leaf spot symptoms. Sample collection at each golf course was terminated after gray leaf spot was confirmed by both methods.

\section{RESULTS}

In vitro assay. In experiment 1 , dot blots of $P$. grisea isolates from perennial ryegrass showed positive reactions as indicated by development of purple color, the intensity of which was comparable to the positive control (Fig. 1A). No difference in intensity of color between the two perennial ryegrass isolates was observed (W. Uddin, unpublished data). The blots of $B$. sorokiniana, Colletotrichum graminicola, Curvularia lunata, Pythium aphanidermatum, R. solani, S. homoeocarpa, the negative controls extraction buffer, and PDA did not develop positive reactions (Fig. 1A). Blots of $M$. nivale developed a purplish tinge, but the weak reaction was easily distinguishable from those of the positive control and the $P$. grisea isolates. In experiment 2 , blots of the $1 \times$ (primary concentration), $0.5 \times, 0.25 \times, 0.13 \times, 0.06 \times$, and $0.03 \times$ dilutions of $P$. grisea cultures yielded positive results. However, there was a decrease in color intensity with decrease in concentration of the antigen solution (Fig. 1B). In experiment 3, blots of the six $P$. grisea isolates from perennial rye-
A

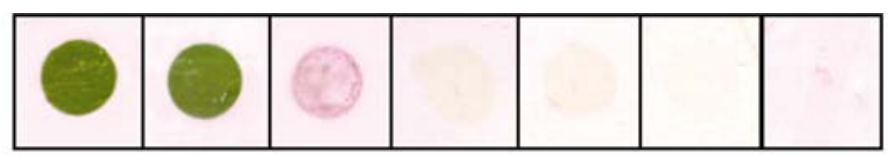

$\begin{array}{lllllll}1 & 2 & 3 & 4 & 5 & 6 & 7\end{array}$

B

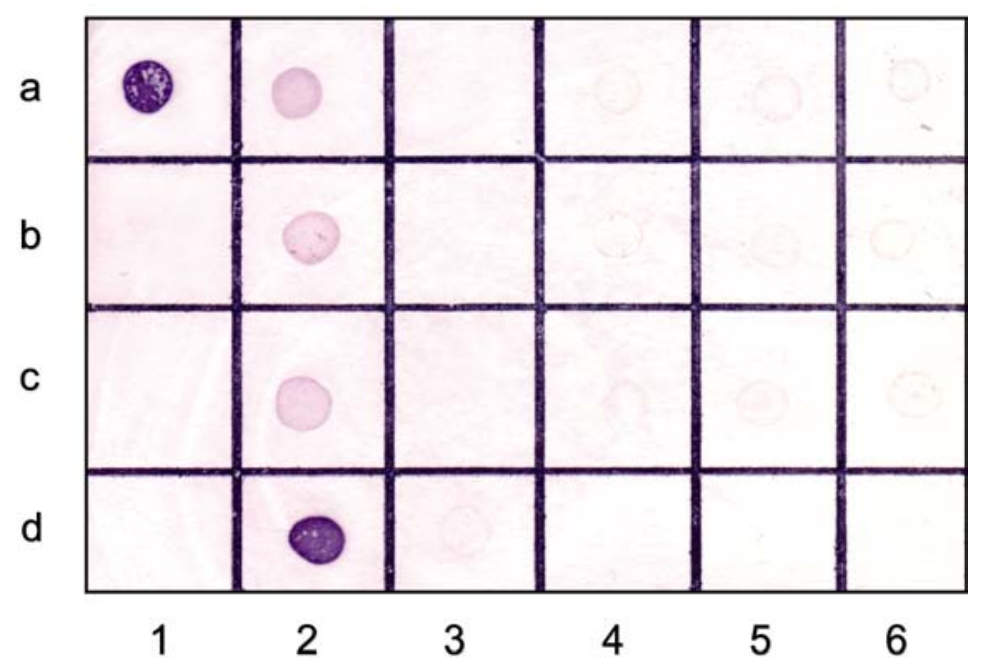

C

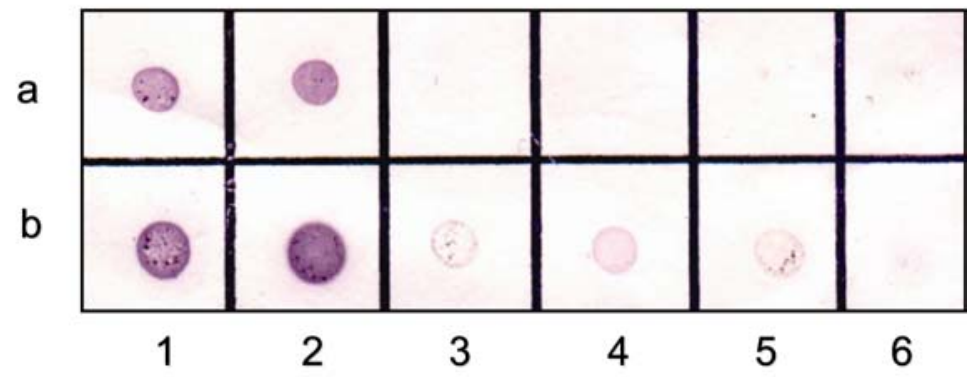

D

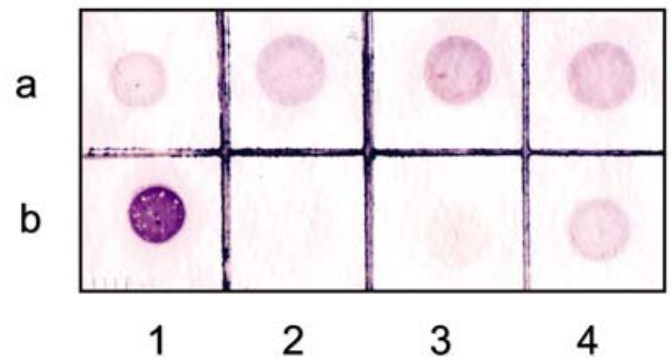

Fig. 2. A, Composite photo of removal of chlorophyll from dot blots of noninfected (blots 1, 2, 4-7) and infected perennial ryegrass (blot 3 ) leaf tissue using $\mathrm{NaOCl}$. $\mathrm{NaOCl}$ concentration: $1=$ none; $2=0.05 \% ; 3=0.5 \%$ (infected) $; 4=0.5 \% ; 5=1.0 \% ; 6=2.6 \% ; 7=5.3 \%$. B, Dot blots of the reactions by Pyricularia grisea and other turfgrass pathogens from symptomatic leaves and culture plates. In vivo (rows $\mathrm{a}, \mathrm{b}$, and $\mathrm{c}$ ): a1 = positive control; negative controls: $\mathrm{b} 1=$ noninfected leaves; $\mathrm{c} 1=$ extraction buffer; in vivo: $\mathrm{a} 2-\mathrm{c} 2=P$. grisea (isolate 02V-01), each blot represents a sample from each container; a3-c3 = Bipolaris sorokiniana; a4-c4 = Rhizoctonia solani; a5-c5 = Sclerotinia homoeocarpa $;$ a6-c6 = Pythium aphanidermatum $;$ in vitro $($ row $\mathrm{d}): \mathrm{d} 1=$ potato dextrose agar; $\mathrm{d} 2=P$. grisea $; \mathrm{d} 3=B$. sorokiniana $; \mathrm{d} 4=R$. solani; $\mathrm{d} 5=S$. homoeocarpa $; \mathrm{c6}=$ Pythium aphanidermatum. $\mathbf{C}$, Dot blots of the reaction of $P$. grisea in perennial ryegrass leaf tissue at various stages of gray leaf spot development. a1, a2, and $\mathrm{b} 1=$ P. grisea (culture; 02V-01); a3 = potato dextrose agar (control); $\mathrm{a} 4-\mathrm{a} 6=$ asymptomatic leaves ( 2 to 3 days after inoculation); $\mathrm{b} 2=$ positive control; $\mathrm{b} 3-\mathrm{b} 5=$ symptomatic leaves (various levels of severity); b6 = noninfected leaves (control). D, Dot blots of the reaction of $P$. grisea in leaf tissue from turf samples with various levels of gray leaf spot severity from golf course fairways in Pennsylvania. a1 = specks; $\mathrm{a} 2=$ leaf spots; $\mathrm{a} 3$ and $\mathrm{a} 4=$ blighted leaves; $\mathrm{b} 1$ = positive control; $\mathrm{b} 2$ = extraction buffer; $\mathrm{b} 3$ = leaves from noninoculated control plants; b4 = partially blighted leaves (tip blight). 
grass collected from various regions of the United States showed positive reactions. There was no notable difference in intensity of blot color among isolates, with the exception of an isolate from New Jersey (NJ1-2), which was slightly lighter than the others (Fig. 1C). In experiment 4, purple color developed in the blots of isolates of $P$. grisea from perennial ryegrass, tall fescue, St. Augustinegrass, finger millet, rice, crabgrass, wheat, and triticale (Fig. 1D).

Removal of chlorophyll from grass leaf tissue. Chlorophyll from leaf tissue that persisted in the antigen suspension following centrifugation was removed by treatment with $\mathrm{NaOCl}$. Application of 0.5 , $1.0,2.6$, or $5.25 \% \mathrm{NaOCl}$ to the membrane eliminated the chlorophyll in the blots. However, chlorophyll was not removed by either $0.05 \% \mathrm{NaOCl}$ or sterilized distilled water (control) (Fig. 2A).

In vivo assay. In the first experiment, positive responses developed both in blots containing $P$. grisea mycelium from culture and in blots containing blighted leaf blades from perennial ryegrass plants inoculated with P. grisea (Fig. 2B). The intensity of the blot color of $P$. grisea from culture was similar to that of the positive control, but intensity of the blot from symptomatic leaves was lighter. There was no reaction in blots of blighted leaves from plants inoculated with $B$. sorokiniana, Pythium aphanidermatum, $R$. solani, or S. homoeocarpa. In some blots of leaves inoculated with these pathogens, sedimentation of fine particles from the dead tissue materials in the blot provided a light orange-brown color, particularly at the periphery of blots. This sedimentation of particles was observed with a dissecting scope. The sediments were removed from the blots with a scalpel and examined under a compound microscope. The particles were leaf tissue debris similar to that from the supernatant of the centrifuged antigen solution. In the second experiment, purple color developed in blots of the antigen solution from the symptomatic leaves of the plants inoculated with $P$. grisea; however, the strength of the reactions varied with the level of disease severity (Fig. 2C). There was no reaction in blots of leaves collected from $P$. grisea-inoculated plants during the latent period or from noninoculated controls.

Analysis of turfgrass samples from golf courses. None of the samples collected in June and July were diagnosed with gray leaf spot. Asymptomatic or dead leaves from the samples tested negative for gray leaf spot using the immunorecognition assay. Further, conidia of $P$. grisea were not produced when the leaves were incubated in the moist chamber. Two samples collected on 3 August 2000 were the first to test positive using the immunorecognition procedure. In this test, there were no reactions in blots of asymptomatic leaves, relatively weak reactions in blots of leaves with specks, necrotic spots, and partially blighted leaves, and stronger reactions in blots of blighted leaves (Fig. 2D). In these samples, no conidia of $P$. grisea were observed on the tissue of the 20 necrotic leaves selected for microscopic identification of the fungus; however, profuse production of conidia of $P$. grisea occurred on necrotic tissue of the leaves following incubation in a moisture chamber for $48 \mathrm{~h}$. During this survey, samples from all sites in New Jersey and all but one in Pennsylvania tested positive for gray leaf spot and produced conidia on necrotic leaves 24 to $96 \mathrm{~h}$ after placement in a moisture chamber. None of the samples submitted from the 10 survey sites in New England tested positive in either the immuno-recognition assay or after incubation in the moisture chamber; however, a sample submitted to the Rhode Island Turfgrass Disease Clinic from a nonsurvey site from Walpole, MA, in September tested positive using the immuno-recognition assay, and gray leaf spot was confirmed by microscopic identification of $P$. grisea. Of the 30 samples (three from each location) positively identified for gray leaf spot by the immunorecognition assay during the survey, conidia of $P$. grisea were readily detected microscopically in only four samples upon arrival at the laboratory.

\section{DISCUSSION}

This is the first documentation of a rapid immuno-recognition assay that can specifically detect the causal agent of gray leaf spot of perennial ryegrass turf. The positive reaction in dot blots of $P$. grisea isolates from perennial ryegrass clearly indicated that the target antigen was recognized by the monoclonal antibody. The positive reaction in dot blots of $P$. grisea cultures was similar to that of the positive control. The antibody-based assay did not react with mycelium of $B$. sorokiniana, Colletotrichum graminicola, Curvularia lunata, Pythium aphanidermatum, R. solani, S. homoeocarpa, or the negative controls (extraction buffer or PDA) in vitro. However, a weak positive reaction developed in the blot of the mycelial suspension of $M$. nivale. It has been reported that certain cross reactivity may occur among different genera and species of fungi in serological assays, as several antigens may be shared by different fungi $(2,12,18,50)$. However, the weak reaction from $M$. nivale did not interfere with the detection of $P$. grisea, as the blot color for these two fungi was strikingly different (Fig. 1A). Furthermore, M. nivale, a coolseason pathogen, infects turf during the fall and winter, depending on geographic region, whereas $P$. grisea is active only during warm and humid conditions in late summer.

In a previous study, isolates of $P$. grisea from rice and grasses varied widely in reaction to a monoclonal antibody (51). Three of 12 isolates of $P$. grisea from rice showed a negative reaction, 5 exhibited weak reactions, and 1 showed a moderate reaction to the target antigen. Isolates of $P$. grisea from St. Augustinegrass or crabgrass showed weak reactions, whereas those from perennial ryegrass and an unknown grass showed negative reactions. In contrast, the antibody used in our study had strong positive reactions to six perennial ryegrass isolates of $P$. grisea from various regions of the United States, whereas one isolate from New Jersey showed a slightly weaker reaction. Additionally, the antibody in our study showed positive reaction to isolates of $P$. grisea from a wide range of gramineous hosts including perennial ryegrass, tall fescue, St. Augustinegrass, crabgrass, wheat, triticale, rice, and finger millet. Among the strains of $P$. grisea tested, strains from crabgrass, finger millet, and rice showed slightly weaker reactions, whereas those from tall fescue, wheat, and triticale showed strong reactions similar to the isolates from perennial ryegrass. A previous study on phylogenetic relationship among strains of $P$. grisea demonstrated that isolates from perennial ryegrass, wheat, and triticale are closely related (45). Conversely, it was reported that the rice strain was not closely related to the perennial ryegrass and wheat strains, and did not infect perennial ryegrass plants. The results of our immunorecognition assay followed a similar pattern among isolates of $P$. grisea from different hosts.

A decrease in color development with decreased sample concentration indicated that signal strength weakened as the target antigen was diluted. Recognition of the target antigen from different tissues of $P$. grisea by monoclonal antibodies can be variable. In a previous study, evaluation of several monoclonal antibodies against $P$. grisea showed that while one antibody reacted strongly with antigens from mycelia but weakly with those from conidia, another antibody reacted strongly with antigens from conidia but weakly with those from mycelia (51). In our study, a target antigen in $P$. grisea from perennial ryegrass recognized by this antibody was evidently mycelial, as conidia were not produced in the 2- to 3-day-old cultures on full-strength PDA. Recognition of target antigen in mycelia is critical from a practical standpoint, since conidia are not always present in samples of perennial ryegrass turf from golf courses affected by gray leaf spot. Therefore, only mycelia from young cultures of $P$. grisea on PDA were used in our study. Further studies need to be conducted to determine whether the target antigen is also present in conidia, and to identify the types of proteins to which the antibody binds.

Development of a standard purple color in the dot blots from in vivo assays was consistent with results of in vitro assays, but reaction to $P$. grisea in the host tissue appeared 
to be weaker than that observed from culture plates or the positive control. The weaker reactions in vivo may be due to dilution of $P$. grisea antigen in host tissue.

Precipitation of leaf tissue in the blots often blocked appearance of purple color. To avoid this problem, two additional steps were included for removal of chlorophyll from the symptomatic and asymptomatic leaves and for removal of dead leaf tissue particles from the necrotic or blighted leaves. There was no negative effect of $\mathrm{NaOCl}$ on dot blot color development when applied following the antigenantibody reaction. $\mathrm{NaOCl}$ did not oxidize the precipitated alkaline phosphatase in the dot blot, except at concentrations greater than $0.5 \%$.

The similarity of symptoms for gray leaf spot, Bipolaris leaf spot, Rhizoctonia blights, and heat and drought stresses poses diagnostic challenges for golf course superintendents. In the northeastern United States, these maladies may co-occur with gray leaf spot during late summer. Our study indicates that gray leaf spot can be distinguished from these problems by using the immuno-recognition assay.

Detection of $P$. grisea in turf samples from golf courses in the northeastern United States was consistent with the in vivo assays. Detection of gray leaf spot was dependent upon disease severity, similar to the pattern observed for inoculated plants.

This study demonstrates that the monoclonal antibody procedure is a promising method for detection of gray leaf spot in symptomatic plants. In plant disease diagnostic clinics, inconsistency of production of $P$. grisea conidia impedes rapid diagnosis of gray leaf spot by microscopy. Turf managers must decide quickly if fungicide application is warranted, since development of gray leaf spot epidemics can be rapid under favorable conditions. Hence, rapid diagnosis of gray leaf spot in turfgrass samples is critical, and application of the immuno-recognition assay has a practical value in disease detection. The antibody procedure may be used in a disease diagnosis laboratory as well as in development of a rapid diagnostic kit for field detection of gray leaf spot.

\section{ACKNOWLEDGMENTS}

We thank the golf course superintendents in Connecticut, Massachusetts, New Jersey, Pennsylvania, and Rhode Island who participated in this survey. Our appreciation goes to Richard Buckley at Plant Diagnostic Clinic, Rutgers University, NJ, for his assistance in turf sample collections in New Jersey.

\section{LITERATURE CITED}

1. Alvarez, A. M., Benedict, A. A., and Mizumoto, C. Y. 1985. Identification of Xanthomonads and grouping of strains of Xanthomonas campestris pv. campestris with monoclonal antibodies. Phytopathology 75:722728

2. Banowetz, G. M., Trione, E. J., and Krygier, B. B. 1984. Immunological comparisons of teliospores of two wheat bunt fungi, Tilletia species, using monoclonal antibodies and antisera. Mycologia 76:51-62.

3. Banttari, E. E., and Goodwin, P. H. 1985. Detection of potato viruses $\mathrm{S}, \mathrm{X}$, and $\mathrm{Y}$ by enzyme-linked immunosorbent assay. Plant Dis. 69:202-205.

4. Cahill, D. M., Cope, M., Gabor, B. K., Gubler, F., and Hyde, G. J. 1994. Cell surface antigens of Phytophthora spores: Biological and taxonomic characterization. Protoplasma 181:213232.

5. Cope, H., and Hardman, A. R. 1994. Synthesis and assembly of flagellar surface antigens during zoosporogenesis in Phytophthora cinnamomi. Protoplasma 180:158-168.

6. De Boer, S. H., and McNaughton, M. E. 1986. Evaluations of immunofluorescence with monoclonal antibodies for detecting latent bacterial ring rot infections. Am. Potato J. 63:533-543.

7. De Boer, S. H., and Wieczorek, A. 1984. Production of monoclonal antibodies to Corynebacterium sepedonicum. Phytopathology 74:1431-1434.

8. Dewey, F. M. 1990. The use of monoclonal antibodies to detect plant invading fungi. Pages 21-25 in: Monoclonal Antibodies in Agriculture. A. Schots, ed. Proc. Symp. Perpectives for Monoclonal Antibodies in Agriculture, Wageningen, The Netherlands.

9. Ellis, M. B. 1971. Dematiaceous Hyphomycetes. Commonwealth Mycological Institute, Kew, Surrey, UK

10. Faris-Mokaiesh, S., Corbiere, R., Lyons, N. F., and Spire, D. 1995. Evaluation of an enzyme-linked immunosorbent assay for detection of Mycosphaerella pinodes in pea seeds. Ann. Appl. Biol. 127:441-455.

11. Gerik, J. S., Lommel, S. A., and Huisman, O. C. 1987. A specific serological staining procedure for Verticillium dahliae in cotton root tissue. Phytopathology 77:261-265.

12. Halk, E. L., and De Boer, S. H. 1985. Monoclonal antibodies in plant disease research. Annu. Rev. Phytopathol. 23:321-350.

13. Halk, E. L., Hsu, H. T., Aebig, J., and Franke, J. 1984. Production of monoclonal antibodies against three ilarviruses and alfalfa mosaic virus and their use as serotyping reagents. Phytopathology 74:367-372.

14. Hardman, A. R., Suzaki, E., and Perkin, J. L. 1986. Monoclonal antibodies to isolate-, species-, genus-specific components on the surface of zoospores and cysts of the fungus Phytophthora cinnamomi. Can. J. Bot. 64:311-321.

15. Harmon, P., Rane, K., Ruhl, G., and Latin, R. 2000. First report of gray leaf spot on perennial ryegrass in Indiana. Plant Dis. 84:492.

16. Hill, E. K., Hill, J. K., and Durand, D. P. 1984. Production of monoclonal antibodies to viruses in the potyvirus group: Use in doublesandwich radioimmunoassay. J. Gen. Virol. 65:525-532.

17. Hsu, H. T., Aebig, J., and Rochow, W. F. 1984. Differences among monoclonal antibodies to barley yellow dwarf viruses. Phytopathology 74:600-605.

18. Ianelli, D., Capparelli, R., Marziano, F., Scala, F., Noviello, C. 1983. Production of hybridomas secreting monoclonal antibodies to the genus Fusarium. Mycotaxon 17:523-532.

19. Johnson, M. R., Anderson, R. L., Kryscio, R. J., and Siegal, M. R. 1983. Sampling procedure for determining endophyte content in tall fescue seed lots by ELISA. Phytopathology 73:1406-1409.

20. Krywienczyk, J., and Dorworth, E. C. 1980. Serological relationships of some species in the genus Pythium. Can. J. Bot. 58:14121417.

21. Landschoot, P. J., and Hoyland, B. F. 1992.
Gray leaf spot of perennial ryegrass turf in Pennsylvania. Plant Dis. 76:1280-1282.

22. Leach, J. E., Ramundo, B. A., Pearson, D. L., and Claflin, L. E. 1987. Dot-immunobinding assay for detecting Xanthomonas campestris pv. holcicola in sorghum. Plant Dis. 71:30-33.

23. Lin, Y., Rundell, P. A., Xie, L., and Powell, C. A. 2000. In situ immunoassay for detection of Citrus tristeza virus. Plant Dis. 84:937-940.

24. MacDonald, J. D., and Duniway, J. M. 1979. Use of fluorescent antibodies to study the survival of Phytophthora megasperma and $P$. cinnamomi zoospores in soil. Phytopathology 69:436-441.

25. Malin, E., Belden, E. L., and Roth, D. 1985. Evaluation of the radioimmunoassay, indirect enzyme linked immunosorbent assay, and do blot assay for the identification of Xanthomonas campestris pv. phaseoli. Can. J. Plant Pathol. 7:217-222.

26. Martin, R. R., and Stace-Smith, R. 1984 Production and characterization of monoclonal antibodies specific to potato leaf roll virus. Can. J. Plant Pathol. 8:1-7.

27. Matthew, J. S., and Brooker, J. D. 1991. The isolation and characterization of polyclonal and monoclonal antibodies to anastomosis group 8 of Rhizoctonia solani. Plant Pathol. 40:67-77

28. Miller, S. A., Grothaus, G. D., Petersen, F. P., and Papa, S. L. 1986. Detection of Pythium blight in turfgrass using a monoclonal antibody-based diagnostic test. (Abstr.). Phytopathology 76:1057

29. Miller, S. A., Grothuas, G. D., Petersen, F. P Rittenburg, J. H., Plumley, K. A., and Lankow, R. K. 1989. Detection and monitoring of turfgrass pathogens by immunoassay. Pages 109-120 in: Integrated Pest Management for Turfgrass and Ornamentals. A. R Leslie and R. L. Metcalf, eds. U.S. Environmental Protection Agency, Washington, DC.

30. Miller, S. A., and Martin, R. R. 1988. Molecular diagnosis of plant disease. Annu. Rev Phytopathol. 26:409-432.

31. Mitchell, L. A. 1988. A sensitive dot immunoassay employing monoclonal antibodies for detection of Sirococcus strobilinus in spruce seed. Plant Dis. 72:664-667.

32. Musgrave, D. R., Grose, T. A., Latch, G. C. M., and Christensen, M. J. 1986. Purification and characterization of the antigens of endophytic fungi isolated from Lolium perenne and Festuca arundinacea in New Zealand. N.Z. J. Agric. Res. 29:121-128.

33. Oulette, G. B., and Benhamou, N. 1987. Use of monoclonal antibodies to detect molecules of fungal plant pathogens. Can. J. Plant Pathol. 9:167-176.

34. Savage, S. D., and Sall, M. A. 1981. Radioimmunoassay for Botrytis cinerea. Phytopathology 71:411-415.

35. Schumann, G. L., and Jackson, N. 1999. First report of gray leaf spot (Pyricularia grisea) on perennial ryegrass (Lolium perenne) in New England. Plant Dis. 83:1073.

36. Sheppard, J. W. 1983. Detection of seedborne bacterial blight of beans. Seed Sci. Technol. 11:561-567.

37. Sherwood, J. L., Sanborn, M. R., and Keyser, G. C. 1987. Production of monoclonal antibodies to peanut mottle virus and their used in enzyme-linked immunosorbent assay and dot immunobinding assay. Phytopathology 77: 1158-1161.

38. Smiley, R. W., Dernoeden, P. H., and Clarke, B. B. 1992. Compendium of Turfgrass Diseases. 2nd ed. American Phytopathological Society, St. Paul, MN.

39. Thingstrup, I., Rozycka, M., Jeffries, P., Rosendahl, S., and Dodd, J. C. 1995. Detection of the arbuscular mycorrhizal fungus Scutellospora heterogama within roots using 
polyclonal antisera. Mycol. Res. 99:12251232.

40. Thornton, C. R. 1996. Detection and quantification of Rhizoctonia solani in soil by monoclonal antibody-based immuno-magnetic bead assay. Soil Biol. Biochem. 28:527-532.

41. Uddin, W., Soika, M. D., Moorman, F. E., and Viji, G. 1999. A serious outbreak of blast disease (gray leaf spot) of perennial ryegrass in golf course fairways in Pennsylvania. Plant Dis. 83:783.

42. Uddin, W., Viji, G., and Stowell, L. 2002. First report of gray leaf spot on perennial ryegrass turf in California. Plant Dis. 86:75.

43. Valent, B., Crawford, M. S., Weaver, C. G., and Chumley, F. G. 1986. Genetic studies of fertility and pathogenicity in Magnaporthe grisea (Pyricularia grisea). Ia. State J. Res. 60:569-594.
44. Van Vuurde, J. W. L., Van Den Bovenkamp, G. W., and Birnbaum, Y. 1983. Immunofluorescence microscopy and enzyme-linked immunosorbent assay as potential routine tests for the detection of Pseudomonas syringae phaseolicola and Xanthomonas campestris pv. phaseoli in bean seed. Seed Sci. Technol. 11:547-559.

45. Viji, G., Wu, B., Kang, S., Uddin, W., and Huff, D. R. 2001. Pyricularia grisea causing gray leaf spot of perennial ryegrass turf: Population structure and host specificity. Plant Dis. 85:817-826.

46. Vincelli, P. 1999. Gray leaf spot: An emerging disease of perennial ryegrass. Turfgrass Trends 7:1-8.

47. White, D. G. 1976. The preparation and use of a fluorescent antibody reagent for the detection of Pythium graminicola. Phytopathology
66:523-525.

48. White, J. G., Lyons, N. F., Wakeham, A. J., Mead, A., and Green, J. R. Serological profiling of the fungal genus Pythium. Physiol. Mol. Plant Pathol. 44:349-361.

49. Wycoff, K. L., Jellison, J., and Ayers, A. R. 1987. Monoclonal antibodies to glycoprotein antigens of a fungal plant pathogen, Phytophthora megasperma f. sp. glycinea. Plant Physiol. 85:508-515.

50. Xia, J. Q., Lee, F. N., Kim, K. S., and Spiegel, F. W. 1993. Characterization of monoclonal antibodies to conidial antigens of Pyricularia grisea. Experimental Mycol. 17:170-181.

51. Xia, J. Q., Lee, F. N., Scott, H. A., and Raymond, L. R. 1992. Development of monoclonal antibodies specific for Pyricularia grisea, the rice blast pathogen. Mycol. Res. 96:867-873. 